\title{
Erratum to: Farewell to the rightist self-employed? 'New self-employment' and political alignments
}

\author{
Giedo Jansen ${ }^{1}$
}

\section{Erratum to: Acta Politica (2016) DOI 10.1057/s41269-016-0030-0}

The article Farewell to the rightist self-employed? 'New self-employment' and political alignments, written by Giedo Jansen, was originally published electronically on the publisher's internet portal (currently www.SpringerLink) on 15/11/ 2016 without open access.

With the author(s)' decision to opt for Open Choice the copyright of the article changed on [date the updated version will be/was published] to (C) The Author(s) 2016 and the article is forthwith distributed under the terms of the Creative Commons Attribution.

4.0 International License (http://creativecommons.org/licenses/by/4.0/), which permits use, duplication, adaptation, distribution and reproduction in any medium or format, as long as you give appropriate credit to the original author(s) and the source, provide a link to the Creative Commons license, and indicate if changes were made.

The online version of the original article can be found under doi:10.1057/s41269-016-0030-0.

Giedo Jansen

giedo.jansen@utwente.nl

1 Faculty of Behavioural, Management \& Social Sciences, Institute for Innovation and Governance Studies, University of Twente, P.O. Box 217, 7500 AE Enschede, The Netherlands 